\title{
Obituary for Steve Hudson
}

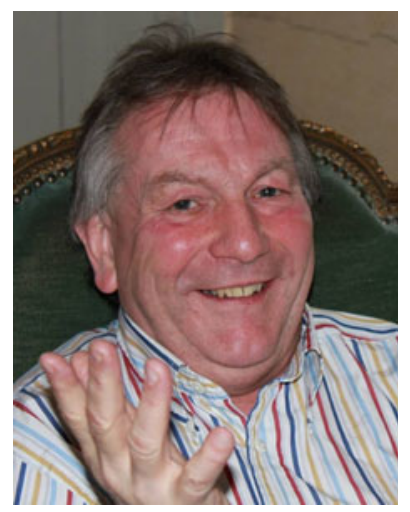

It is with great sadness that we learned of the death of Prof. Steve (S.A.) Hudson, from the University of Strathclyde. Prof. Hudson lived in Edinburgh, Scotland. He passed away November 21, at the age of 58 .

Steve Hudson's work and life were dedicated to Clinical Pharmacy practice and pharmaceutical care. He taught bedside clinical pharmacy to many pharmacist in hospitals throughout Europe and the rest of the world. His students loved him for his motivation and drive. For his colleagues he was a very good friend with a great sense of humour.

Steve also had an important role in the journal Pharmacy World \& Science. He was part of he Editorial Board of the journal for some time, and he reviewed many papers. He applauded the recent name change of the journal.

Steve was one of the key persons in ESCP for many years. In the European Society for Clinical Pharmacy, he took an active part in almost all symposia. He initiated and taught many courses, chaired Special Interest Groups and organised several Master classes. Because of his role in the society, he was recognized as Fellow of ESCP in 2009.

I am grateful for all that Professor Steve Hudson has done for clinical pharmacy and pharmaceutical care. I am also grateful for the many discussions that we could have. Recently he initiated the web-based discussion of the definition of clinical pharmacy, which his colleagues now certainly will continue and finalise.

Steve was a truly remarkable person, keen on clinical pharmacy but also a very social and socializing person with a lot of humour. He loved to travel and often shared his other interests with us: good food, music, Zappa, and jazz.

We lost a good friend and a helpful and respected teacher.

Foppe van Mil, $\mathrm{PhD}$

Editor-in-chief.

International Journal of Clinical Pharmacy. 